\title{
ASPEKTY USTROJOWE STOSUNKÓW WEWNĄTRZPARTYJNYCH
}

DOI: http://dx.doi.org/10.12775/TSP-W.2016.007

Summary. The internal organisation of political parties in Poland. The Author stresses that the internal organisation of political parties in Poland is regulated by their own statutes. As a consequence, the parties have the freedom to shape their structure how they wish under the condition of complying with democratic principles. Polish law does not specify, however, to what extent these principles ought to be implemented. Accordingly, it can be affirmed that, in practice, only these parties in which electionbased transfer of the leadership does not occur, are prohibited.

Keywords: political parties; internal organisation of political parties in Poland; democratic principles.

Riassunto. Nell'ordinamento polacco l'organizzazione interna dei partiti. Il presente contributo affronta il tema dei rapporti interni dei partiti politici in Polonia. Nell'ordinamento polacco l'organizzazione interna dei partiti è regolata dalle norme statutarie. Di conseguenza, i partiti, obbligati al pieno rispetto dei principi democratici, sono liberi di definirla. La legislazione polacca non specifica però come misurare il grado di osservanza del metodo democratico. Si può dunque affermare che in practica è vietata l'esistenza soltanto di tali partiti politici che si astengano dal traferimento di potere all'interno del partito per mezzo di elezioni.

Parola chiave: partiti politici; rapporti interni dei partiti politici in Polonia; principi democratici.

Partie polityczne stanowią nietypowy podmiot we współczesnych państwach demokratycznych. Specyfika ta zaczęła być dostrzegana już w wieku 
XIX, kiedy to z racji swoich celów zaczęto odróżniać je od innych zrzeszeń, w szczególności od stowarzyszeń ${ }^{1}$. W połowie XX w. osobliwość tę zaczął dostrzegać również prawodawca, który najpierw na poziomie konstytucyjnym, a potem i ustawowym przyjmował rozwiązania, które miały z jednej strony służyć uwypukleniu owej specyfiki, z drugiej zaś stworzyć mechanizmy kontrolne związane $\mathrm{z}$ ich działalnością, $\mathrm{w}$ tym działalnością $\mathrm{w}$ ramach demokratycznego systemu politycznego ${ }^{2}$. Zresztą wyjątkowość partii politycznych odróżniająca je od innych zrzeszeń widoczna jest także w podejściu charakterystycznym dla analizy funkcjonalnej ustroju, czego wyrazem jest chociażby odmienna strategia ich działania, podporządkowana $\mathrm{z}$ reguły osiąganiu sukcesów wyborczych.

Jak wspomniałem powyżej, funkcjonowanie partii politycznych związane jest obecnie z ich instytucjonalizacją, a więc objęciem ich szeroką regulacją prawną. Nie inaczej jest w Rzeczypospolitej Polskiej, gdzie także partie polityczne muszą działać w oparciu o przepisy konstytucji ${ }^{3}$, ustawy o partiach politycznych ${ }^{4}$, a także przepisy ich regulacji wewnętrznych ze statutami partyjnymi na czele. To właśnie te ostatnie są podstawowym źródłem regulującym zasady organizacji wewnętrznej polskich stronnictw politycznych ${ }^{5}$, co jednak nie oznacza, że akty prawa powszechnie obowiązującego nie odnoszą się w żaden sposób do tej problematyki. Wręcz przeciwnie, zarówno konstytucja, jak również aktualna ustawa o partiach politycznych tworzą fundamenty, na których muszą być budowane ugrupowania polityczne, choć regulacje te nie są tak szczegółowe, jak np. w Niemczech, gdzie zarówno sposób organizacji partii politycznych, jak i ich stosunków wewnętrznych został precyzyjnie uregulowany w ustawie ${ }^{6}$. Obecny stan prawny stwarza polskim partiom politycznym daleko idącą swo-

1 Z. Wachlowski, Stronnictwa polityczne w państwie współczesnym, Warszawa 1939, s. 1149-150; M. Sobolewski, Zasady demokracji burżuazyjnej i ich zastosowanie, Warszawa 1969, s. $182-183$.

2 Por.. M. Chmaj, W. Sokół, M. Żmigrodzki, Teoria partii politycznych, Lublin 1997, s. 74.

${ }^{3}$ Konstytucja Rzeczypospolitej Polskiej z dnia 2 kwietnia 1997 r. (Dz.U. Nr 78, poz. 483 ze zm.).

${ }^{4}$ Ustawa z dnia 27 czerwca 1997 r. o partiach politycznych (t.j. Dz.U. z 2011 r., Nr 155, poz. 924 ze zm.).

${ }^{5} \mathrm{~W}$ doktrynie podkreśla się, że są one wyrazem wewnętrznej autonomii partii politycznych, por. M. Granat, A. Gorgol, J. Sobczak, Ustawa o partiach politycznych. Komentarz, Warszawa 2000, s. 35.

${ }^{6} \mathrm{~Np}$. pojawiają się tam wskazane obligatoryjne organy partyjne (art. 8-9) czy też określenie sposobu wyłaniania zgromadzeń partyjnych (art. 13); Gesetz über die politischen Parteien v. 31.01.1994 BGBl. I S. 149 ze zm. 
bodę w kształtowaniu swoich organów oraz struktur terenowych, co zresztą jest rozwiązaniem typowym dla większości państw tej części Europy

Konstytucja RP z 1997 r. poświęca partiom politycznym stosunkowo niewiele miejsca, ograniczając się w zasadzie do dwóch artykułów, a także ich rozwinięcia w zakresie realizacji funkcji wyborczej przez stronnictwa polityczne oraz ich delegalizacji. Z punktu widzenia stosunków wewnątrzpartyjnych kluczowe znaczenie mają art. 11 oraz art. 13 ustawy zasadniczej. $\mathrm{Z}$ ich treści wynikają bowiem wytyczne dotyczące struktury wewnętrznej partii politycznych. Po pierwsze, istotną wskazówką jest stwierdzenie, że zrzeszają one obywateli polskich „na zasadach dobrowolności i równości”. Oznacza to, że owa dobrowolność powoduje nie tylko zakaz wprowadzania obowiązkowej przynależności do partii politycznych, ale również i jakiekolwiek formy stosowania innych form nacisku na osoby w celu zmuszenia ich do przystępowania do partii politycznych. Natomiast sam sposób uregulowania zasad przystępowania do partii politycznych nie został już prawnie unormowany ani na poziomie konstytucyjnym, ani ustawowym. Wszelkie te regulacje muszą pozostawać jednakże w zgodnie ze wspomnianą zasadą równości.

Nieco większy problem można mieć z dalszą częścią treści art. 11, który stanowi, że partie są tworzone „w celu wpływania metodami demokratycznymi na kształtowanie polityki państwa”. Z pozoru mogłoby się wydawać, że owe metody demokratyczne dotyczą działalności partii politycznej, lecz w mojej ocenie należy rozumieć je nieco szerzej. Metody demokratyczne muszą bowiem dotyczyć także wewnętrznej sfery funkcjonowania partii politycznych ${ }^{8}$, choć oczywiście nie muszą one występować w sposób absolutny, lecz jedynie nie pozwalać na powstawanie partii typu wodzowskiego, w których najważniejsze organy partyjne nie są wyłaniane $\mathrm{w}$ drodze wyborów. Zresztą podobne stanowisko zajął również Trybunał Konstytucyjny, który stwierdził, że ,niedemokratyczne elementy wewnątrzorganizacyjne nie zawsze muszą mieć bezpośredni i istotny wpływ na wypełnianie przez partię jej roli ustrojowej lub stosowane przez nią zewnętrzne metody działania. W związku z tym swoboda kształtowania wewnętrznych struktur i zasad funkcjonowania partii nie może być ograniczana jak długo nie zagraża wypełnianiu przez partię jej konstytucyjnej roli lub jak długo nie wyklucza demokratyczności metod, jakimi partia zamierza wpływać

${ }^{7}$ M. Granat, Partie polityczne w konstytucjach państw Europy Środkowej $i$ Wschodniej, w: Partie polityczne we wspótczesnym konstytucjonalizmie, red. M. Granat, P. Policastro, J. Sobczak, Lublin 2001, s. 253.

${ }^{8}$ Por. J. Sobczak, Konstytucyjna wolność tworzenia partii politycznych w Polsce, w: Partie polityczne we wspótczesnym konstytucjonalizmie, red. M. Granat, P. Policastro, J. Sobczak, Lublin 2001, s. 192. 
lub wpływa na kształtowanie polityki państwa. Brak demokracji wewnątrzorganizacyjnej musi natomiast być brany pod uwagę przy orzekaniu o zgodności z konstytucją celów lub działalności partii politycznych, jeżeli uniemożliwia lub choćby tylko w istotny sposób ogranicza spełnianie przez partię jej konstytucyjnej roli lub przekłada się bezpośrednio na zakładane lub stosowane przez nią metody kształtowania polityki państwa. Oznacza to konieczność dokonywania ocen odnoszonych zawsze do konkretnego przypadku, przy czym oceny te powinny obejmować całokształt założeń programowych, zasad statutowych i praktyk stosowanych przez daną partię polityczną" . Można bowiem uznać, że funkcjonowanie partii w sposób niedemokratyczny przekładać się będzie na jej cele i działania związane z kształtowaniem polityki państwa, w przypadku gdy uzyska ona wpływ na jej prowadzenie.

Drugim elementem związanym ze stosunkami wewnątrzpartyjnymi, a wskazanym na poziomie konstytucyjnym jest zakaz utajniania struktur lub członkostwa. Dotyczy to wszelkich struktur partyjnych, zarówno na szczeblu centralnym, jak również i terenowym, a także wszystkich członków partii politycznej. W tym kontekście można mieć jednak wątpliwości, jaka jest relacja art. 13 Konstytucji RP do jej art. 54, czyli wolności wyrażania swoich poglądów w aspekcie negatywnym, a więc prawa do ich nieujawniania, szczególnie w sytuacji, gdy będą one odmienne od poglądów prezentowanych przez ugrupowania rządzące. Zwracano również uwagę na kolizję art. 13 z konstytucyjnym prawem do ochrony danych osobowych ${ }^{10}$. W efekcie zgodzić trzeba się z poglądem W. Sokolewicza, że pojęcie utajniania członkostwa oznacza jedynie jako zakaz „niezezwalający na «sekretną» przynależność pewnych kategorii osób [...] do partii bądź zabraniający «utajnionego» werbunku nowych członków"11, a nie zaś konieczności ujawniania danych osobowych osób, które przystąpiły do poszczególnych stronnictw politycznych.

Ustawa o partiach politycznych tylko w niewielkim stopniu rozwinęła postanowienia ustawy zasadniczej dotyczące ich struktur wewnętrznych. Przede wszystkim dokonane zostało to w jej art. 8. Przepis ten stwierdza, że „partie polityczne kształtują swoje struktury oraz zasady działania zgodnie z zasadami demokracji, w szczególności przez zapewnienie jawności tych struktur, powoływania organów partii w drodze wyborów i podejmowania uchwał większością głosów”. Tym samym demokratyczność związana z organizacją wewnętrzną

9 Zob. Wyrok TK z dnia 8 marca 2000 r., Pp 1/99, OTK ZU z 2000 r., nr 2, poz. 58.

${ }^{10}$ K. Complak, Normy pierwszego rozdziału Konstytucji RP, Wrocław 2007, s. 181.

11 W. Sokolewicz, Uwaga 18 do art. 13, w: Konstytucja Rzeczypospolitej Polskiej. Komentarz, $t$. V, red. L. Garlicki, Warszawa 2007, s. 20. 
partii politycznej i jej funkcjonowaniem została określona w sposób wyraźny, jednakże bez jej szczegółowego ukształtowania na tym poziomie. Poza powtórzeniem wymogu jawności struktur, co wynikało już bezpośrednio z regulacji konstytucyjnej, ustawodawca wskazał dwa inne niezbędne elementy związane z funkcjonowaniem stronnictw politycznych, które stanowią konsekwencje demokratycznych metod jej działania. Konieczność powoływania organów partii w drodze wyborów wskazuje, że dotyczy to wszystkich jej organów, lecz pozostawia możliwość obsadzania w inny sposób tych stanowisk, które organami partii - w myśl jej statutu - nie są, przede wszystkim stanowisk o charakterze administracyjnym. Ponadto nie został wskazany sposób, w jaki wybory te są przeprowadzane. Przede wszystkim nie pojawiły się żadne rozwiązania prawne, które chociażby preferowałyby wybory o powszechnym i bezpośrednim charakterze, przynajmniej w stosunku do osoby, mającej być liderem ugrupowania. W efekcie to statut partii będzie miał określić zasady owych wyborów, mając w tej sferze daleko idącą swobodę. Podobnie wygląda sytuacja dotycząca uchwał. Można przyjąć, że zasadą powinna być tu zwykła większość, choć w statucie partii może być wskazane, że niektóre z nich mogą wymagać większości bezwzględnej czy też kwalifikowanej (np. uchwalanie czy zmiana statutu), w zależności od tego, czy dane ugrupowanie będzie chciało im nadać szczególną rangę właśnie poprzez wprowadzenie szczegółowego, utrudnionego trybu jej podjęcia.

W konsekwencji zarówno ustawa zasadnicza, jak i ustawa o partiach politycznych tworzą jedynie pewne zręby związane z funkcjonowaniem ugrupowań politycznych w Polsce. Natomiast rzeczywiste ich ukształtowanie w ramach danej partii politycznej dokonywane jest - co już zauważono - na poziomie jej statutu, który w świetle art. 9 ust. 1 „określa jej cele, strukturę i zasady działania”. Przepis ten wskazuje przykładowo elementy, które powinny być uregulowane w statucie. Z punktu widzenia jej wewnętrznej organizacji szczególne znaczenie ma tutaj określenie: sposobu nabywania i utraty członkostwa, praw i obowiązków członków, organów partii, w tym organów ją reprezentujących na zewnątrz oraz uprawnionych do zaciągania zobowiązań majątkowych, ich kompetencje oraz czas trwania ich kadencji, trybu dokonywania wyboru organów partii i uzupełniania składów tych organów oraz zasad tworzenia i znoszenia terenowych jednostek organizacyjnych partii. Oczywiście statut może regulować również cały szereg innych kwestii związanych z wewnętrznym funkcjonowaniem stronnictwa politycznego, o ile organ go przyjmujący uzna to za stosowne ${ }^{12}$.

12 Przykładem tego może być dopuszczalność tworzenia frakcji wewnątrzpartyjnych, których istnienie - pod nazwą platform programowych - przewiduje art. 15 statutu SLD. 
Jak słusznie jednak zauważył Trybunał Konstytucyjny, postanowienia statutu, w tym również odnoszące się do sfery organizacyjnej, muszą znajdować swoje zastosowanie w praktyce funkcjonowania każdej z partii politycznych. „Partia, która poprzestaje na wpisie do ewidencji «fasadowego», choć niesprzecznego z Konstytucją statutu, w rzeczywistości opierając swą działalność na innej, niezgodnej z Konstytucją regulacji, musi się liczyć z zastosowaniem wobec niej kontroli represyjnej, która koncentruje się nie na analizie postanowień aktów normujących jej działalność, lecz na ocenie rzeczywistej działalności"'13. W efekcie, gdyby faktyczna organizacja partii odbiegała od statutowej, naruszając jednocześnie podstawowe zasady konstytucyjne dotyczące jej działalności, byłaby to podstawa do delegalizacji takiego ugrupowania politycznego.

Brak uniformizacji struktur partii politycznych powoduje, że w praktyce ustrojowej Rzeczypospolitej Polskiej występuje istotna różnorodność zasad wewnętrznej organizacji i funkcjonowania partii politycznych. Przede wszystkim wynika to $\mathrm{z}$ charakteru danej partii, sposobu jej powstania ${ }^{14}$ oraz stopnia jej wewnętrznej demokratyzacji, a także liczebności ugrupowania, choć - czego nie można pominąć - istotne znaczenie dla tych elementów mają też konkretne okoliczności polityczne, które mogą mieć szczególny wpływ na to, czy partia jest organizacją scentralizowaną, czy też wewnętrznie demokratyczną. Mimo to w dalszej części opracowania skoncentruję się przede wszystkim na metodzie dogmatycznej poddając analizie przede wszystkim wewnętrzne akty najważniejszych stronnictw politycznych w Polsce, przyjmując, że kryterium wyróżnienia tych partii będzie przekroczenie w wyborach do Sejmu progu 3\% głosów ${ }^{15}$, choć incydentalnie będę też wskazywał na rozwiązania występujące w innych polskich partiach politycznych. $\mathrm{W}$ efekcie badaniu poddanych zostało siedem statutów partii politycznych ${ }^{16}$, które - co zostanie wskazane - opiera się często na odmiennych założeniach ideowych, także w zakresie organizacji i funkcjonowania partii politycznych.

13 Zob. Postanowienie TK z dnia 16 lipca 2003 r., Pp 1/02, OTK ZU z 2003 r., nr 6A, poz. 71.

${ }^{14}$ Szczególnie widoczne jest to $\mathrm{w}$ przypadku partii politycznych powołanych przez pojedyncze osoby.

${ }^{15}$ W przypadku koalicji Zjednoczona Lewica skupię się na jej głównym podmiocie, czyli na Sojuszu Lewicy Demokratycznej.

${ }^{16}$ Są to statuty: Prawa i Sprawiedliwości (http://pis.org.pl/document/archive/download/122), Platformy Obywatelskiej (http://www.platforma.org/dokumenty/statut-po), Nowoczesnej Ryszarda Petru (http://bip.nowoczesna.org/index.php/statut-partii), Polskiego Stronnictwa Ludowego (http://psl.pl/upload/pdf/dokumenty/Dokumenty_X_Kongres_PSL/Statut_PSL.pdf), Sojuszu Lewicy Demokratycznej (http://www.sld.org.pl/public/ckfinder/userfiles/files/STATUT_konwencja20160521.pdf), Partii KORWiN (https://www.partiakorwin.pl/statut/) i Partii Razem (http:// partiarazem.pl/wp-content/uploads/2016/05/Statut-Partii-Razem.pdf) [07.06.2016]. 
Pierwszym analizowanym obszarem jest struktura wewnętrznych organów partii politycznych. Można stwierdzić, że ich kształt pokazuje szerokie spektrum możliwych rozwiązań, zarówno pod względem nazewnictwa tych organów, jak też ich uprawnień i obowiązków. Prawie wszystkie z badanych statutów stronnictw politycznych przewidują występowanie lidera partii politycznej ${ }^{17}$, choć i tu użyta nomenklatura jest rożna. W przypadku trzech partii na ich czele stoi przewodniczący (Nowoczesna, SLD, PO), w trzech innych - prezes (PiS, KORWiN, PSL). Jedynym wyjątkiem jest Partia Razem, która ze względów ideologicznych sprzeciwia się jednoosobowemu przywództwu partii politycznej ${ }^{18}$, a tym samym nie ma wyraźnie umocowanego w statucie lidera. Niejednolicie określona została także pozycja lidera partii. Najsilniejszą pozycję posiada prezes PiS, który został określony jako najwyższa władza wykonawcza partii (art. 15 ust. 1 Statutu). Przekłada się to na jego kompetencje, wśród których wyróżnić warto reprezentowanie PiS na zewnątrz, kierowanie bieżącą działalnością ugrupowania, pracami klubu parlamentarnego Rady Politycznej oraz Komitetu Politycznego, przedkładanie do akceptacji Komitetu Politycznego kandydatów w wyborach ogólnokrajowych i europejskich czy też powoływanie pełnomocnika PiS w przypadku rozwiązania organizacji lokalnych czy regionalnych partii. Z kompetencji tych jednoznacznie można wskazać, że - szczególnie w sferze personalnej - to prezes partii może w dużym stopniu samodzielnie wpływać na kierunek rozwoju ugrupowania oraz też obsadzania stanowisk zarówno wewnątrz partii, jak i w organach przedstawicielskich. Silna pozycja wyróżnia także prezesa partii KORWiN, który również jest uznawany w statucie za najwyższy organ wykonawczy ( $\$ 37$ ust. 1). Co istotne, korzysta on też z domniemania kompetencji, gdyż należą do jego uprawnień wszystkie sprawy, które nie należą do kompetencji innych władz partii. Spośród wymienionych kompetencji prezesa wskazać trzeba bieżące kierowanie działalnością partii, w tym pracami klubu parlamentarnego, zwoływanie posiedzeń jej organów czy reprezentowanie partii w życiu publicznym, społecznym i politycznym. Warto zauważyć jednak, że nie zostały mu wyraźnie przyznane kompetencje w sferze personalnej. Inaczej wygląda natomiast pozycja prawna prezesa PSL. Co specyficzne, nie został on wymieniony wśród władz naczelnych partii, a jedynie określono go mianem organu naczelnego PSL (art. 62). Stosunkowo wąski jest również katalog jego kompetencji, w dodatku wymieniony w formie katalogu zamkniętego. Wskazano wśród nich: reprezentowanie

17 Warto wspomnieć, ze w Partii Zieloni - wzorem innych europejskich stronnictw z tej rodziny politycznej - występują dwaj przewodniczący, z których jedna osoba jest kobietą, druga - mężczyzną ( $\$ 40$ w związku z $§ .14$ ust. 2 Statutu), http://zieloni2004.pl/statut2013.pdf [08.06.2016].

18 A. Wiśniewska, Dramat partii Razem, Dziennik Opinii nr 295/2015 (1079). 
partii na zewnątrz, przewodniczenie Naczelnemu Komitetowi Wykonawczemu, realizowanie uchwał Kongresu, Rady Naczelnej i NKW, realizowanie i odpowiadanie za bieżącą politykę PSL, nadzorowanie pracy biura NKW. W efekcie kompetencje te głównie mają charakter administracyjny.

W ugrupowaniach, które posiadają swojego przewodniczącego, jest on jednym z organów wewnętrznych partii, przy czym jedynie w przypadku SLD wyraźnie wskazano, że jest to organ wykonawczy. W statutach Nowoczesnej oraz PO przewodniczący kierują partią, a ponadto - podobnie jak i przewodniczący SLD - zwołują jej organy. Przewodniczący tej pierwszej partii (Nowoczesnej) uzyskuje również istotne uprawnienia wykonywane samodzielnie, jak powoływanie i odwoływanie sekretarza generalnego partii, skarbnika oraz wiceprzewodniczących, a także przedstawianie list kandydatów w wyborach centralnych i do PE, co w dużej mierze pozwala zaliczyć to stronnictwo do ugrupowań o przywództwie jednoosobowym.

Pomimo pewnego zróżnicowania uprawnień prezesa (przewodniczącego) trudno jest, w oparciu o wyłącznie statutowe regulacje pozycji wewnątrzpartyjnej lidera, stwierdzić, że można mówić o występowaniu ugrupowań o jednoosobowym kierownictwie. O tym decyduje bowiem nie tylko sposób regulacji kompetencji takiej osoby, ale również i praktyka funkcjonowania poszczególnych partii, a czasami nawet umieszczenie nazwiska takiego lidera w pełnej nazwie partii politycznej (np. Nowoczesna Ryszarda Petru). Niemniej jednak sama analiza unormowań statutowych pozwala wyciągnąć pewne wnioski, co można zaobserwować szczególnie we wspomnianym już jednoznacznym stwierdzeniu statutów PiS i KORWiN, przesądzających o traktowaniu prezesa jako najwyższego organu wykonawczego tych ugrupowań.

Osobną kwestią jest sposób wyboru lidera stronnictwa politycznego. I tutaj tylko PO, a także w pewnym stopniu SLD, zdecydowały się na wybory powszechne. W tej pierwszej partii nie ma obecnie innego sposobu wyboru przewodniczącego. W wyborach tych mogą uczestniczyć wszyscy członkowie PO. Natomiast do kandydowania wymagane jest zgłoszenie kandydatury przez co najmniej 10 członków Rady Krajowej, co uniemożliwia oddolne zgłaszanie kandydatów. Wybranym na przewodniczącego jest ten kandydat, który uzyskał bezwzględną większość głosów, a gdyby żaden z nich takiej większości nie osiągnął, przeprowadzana jest II tura wyborów, w której uczestniczą dwaj kandydaci z najlepszymi wynikami osiągniętymi w I turze. Wybrany zostaje ten z nich, który uzyska większą liczbę głosów. Wybory przewodniczącego PO przeprowadzane są wyłącznie w drodze głosowania korespondencyjnego oraz elektronicznego ${ }^{19}$.

19 Warto dodać, że po ostatnich wyborach w 2016 r. nie podano, która z form głosowania była częściej wykorzystywana przez członków partii. 
Jak wspomniałem, nieco inaczej wygląda wybór przewodniczącego SLD, gdzie wybory powszechne mają charakter opcjonalny i odbywają się wyłącznie wtedy, gdy zdecyduje tak Krajowa Konwencja albo Rada Krajowa SLD. W przeciwnym wypadku przewodniczącego wybiera Kongres SLD, ewentualnie w sytuacjach nagłych - Krajowa Konwencja SLD. Zasady przeprowadzania powszechnych wyborów przewodniczącego nie zostały ustalone w statucie, lecz każdorazowo ustala je organ decydujący o takiej formie wyboru lidera partii ${ }^{20}$. Warunkiem dokonania wyboru jest uzyskanie przez jednego z kandydatów bezwzględnej większości głosów.

Pozostałe ugrupowania przyjęły odmienną formułę wyborczą, w której liderzy (prezes, przewodniczący) wybierani są przez organy partii. W Nowoczesnej dokonuje tego Konwencja, pochodząca z wyborów przedstawicielki członków, w Partii KORWiN - Kongres, również wyłoniony w demokratycznych wyborach, w PiS - Kongres Partii, w skład którego wchodzą wybrani delegaci, a także osoby piastujące funkcje partyjne i państwowe, w PSL - Kongres PSL, o składzie zbliżonym do Kongresu PiS, a w okresie pomiędzy Kongresami Rada Naczelna PSL. Zróżnicowana jest też kadencja, na jaką wybierani są liderzy poszczególnych stronnictw, wynosząc od 2 (Nowoczesna) do 4 lat (PSL, SLD). Warto dodać, że w statucie PO określono, że kadencja może trwać od 2 do 4 lat, a jej długość określa Rada Krajowa Partii.

Drugim z organów wykonawczych w partiach politycznych jest organ uprawniony do reprezentowania ugrupowania w stosunkach zewnętrznych. W tym przypadku również nazewnictwo bywa różnorodne, choć najczęściej organem takim jest Zarząd (Zarząd Nowoczesnej, Zarząd Krajowy SLD, Zarząd Krajowy PO, Zarząd Krajowy Partii KORWIN, Zarząd Krajowy Razem). Jednakże zgodnie ze statutem PiS, organem takim jest Komitet Polityczny, zaś statutem PSL - Naczelny Komitet Wykonawczy. Także liczebność takich organów nie jest jednolita. W przypadku Zarządu Krajowego Razem statut określił jedynie minimalną jego liczebność na co najmniej 7 członków, natomiast Zarząd Nowoczesnej od 3 do 11 członków. W innych partiach kolegialny organ wykonawczy jest liczniejszy (w PSL do 20 osób), choć w większości przypadków nie została określona wyraźna liczba członków takiego organu, pozostawiając jej ustalenie organom uchwałodawczym (SLD, PiS, PO). W większości tych partii

${ }^{20}$ W 2015 r. władze partii zdecydowały o przeprowadzeniu powszechnych wyborów przewodniczącego, jednakże jeżeli w I turze żaden z nich nie uzyska bezwzględnej większości głosów, to wybór dokonywany był przez Kongres SLD spośród dwóch kandydatów, którzy uzyskali najlepsze wyniki w głosowaniu powszechnym członków partii. 
część mandatów w organie wykonawczym obsadzana jest z racji piastowanych stanowisk w partii ${ }^{21}$.

Kilka słów warto poświęcić Zarządowi Krajowemu Razem, gdyż z racji braku lidera tej partii, to właśnie ZK pełni takiego kolegialnego szefa partii ${ }^{22}$, zresztą o wyjątkowo krótkiej, bowiem rocznej kadencji. Nie analizując, czy z punktu widzenia polityki partyjnej jest to rozwiązania korzystne dla ugrupowania, czy też nie, odnieść się jednak trzeba do tego, że twórcy statutu Partii Razem widzą mimo wszystko konieczność wykreowania osób, które staną się swoistą „twarzą” stronnictwa. Stąd też spośród członków Zarządu powoływani są koordynatorzy: do spraw działalności organizacyjnej, działalności organów terenowych oraz działalności medialnej. O ile dwóch pierwszych koordynatorów można porównać do instytucji sekretarza generalnego, który znany jest wielu polskim partiom politycznym i stanowi podmiot administrujący działalnością partyjną ${ }^{23}$, o tyle koordynator działalności medialnej może pełnić zastępczo rolę swoistego lidera, którego wyborcy utożsamiają z partią.

Niejednorodny jest też kształt organów uchwałodawczych w poszczególnych partiach, choć wszystkie te organy wyłaniane są przez najwyższy organ stronnictwa, jakim jest Kongres (ewentualnie Konwencja). Zresztą Kongresy (Konwencje) też pełnią rolę uchwałodawczą, aczkolwiek nie są to organy o stałym charakterze. Niemniej jednak w każdej badanej partii politycznej delegaci na Kongres (Konwencję) wyłaniani są - przynajmniej w znaczącej części w sposób demokratyczny, aczkolwiek nie zawsze według zbliżonych algorytmów. W niektórych ugrupowaniach wprowadzono bowiem liczbę wybieranych delegatów powiązaną z liczbą członków ${ }^{24}$, w innych liczba ta uzależniona jest

${ }^{21}$ W SLD są to przewodniczący SLD, sekretarz generalny, wiceprzewodniczący, przewodniczący klubu parlamentarnego, przewodniczący zespołu parlamentarzystów europejskich, przewodniczący FMS, przewodnicząca platformy programowej kobiet, w PO - przewodniczący PO, przewodniczący regionów, do pięciu wiceprzewodniczących partii, przewodniczący klubu parlamentarnego, sekretarz generalny, w Partii KORWiN - prezes partii, przewodniczący Rady, wiceprezesi partii, przewodniczący klubu albo koła parlamentarnego, skarbnik krajowy, sekretarz krajowy oraz prezesi zarządów regionów, w PiS - prezes, prezes honorowy, przewodniczący klubu parlamentarnego, wiceprezesi, przewodniczący Komitetu Wykonawczego i skarbnik oraz parlamentarzyści pełniący funkcje w Prezydium Sejmu, Senatu lub PE.

${ }^{22}$ Dodać trzeba, że w zarządzie tej partii, jak i innych jej organach kolegialnych obowiązuje parytet płci (art. 20 ust. 1 statutu).

${ }^{23}$ Sekretarz Generalny przewidziany został w statutach: PO, Nowoczesnej, SLD. Podobny charakter ma Sekretarz Krajowy w Partii KORWiN, a częściowo także Przewodniczący Komitetu Wykonawczego PiS.

${ }^{24}$ Statut Nowoczesnej określa w art. 11 ust. 3, że delegaci są wybierani w regionach w proporcji: jeden delegat na każdych rozpoczętych dwudziestu członków, natomiast Statut Partii KORWiN w $§ 30$ ust. 3 stanowi, że na każdych 10 członków partii w okręgu przypada jeden delegat, 
od liczby delegatów z urzędu uczestniczących w Kongresie ${ }^{25}$, a w jeszcze innych określana jest ona każdorazowo w okresie poprzedzającym zwołanie Kongresu (Konwencji) ${ }^{26}$. W zasadzie wszystkie ugrupowania (poza Partią Razem) przewidują uzyskanie mandatu delegata przez osoby funkcyjne w partii politycznej ${ }^{27}$ lub też zajmujące określone stanowiska w organach albo instytucjach publicznych $^{28}$. Natomiast w miarę jednolite są kompetencje Kongresu (Konwencji), wśród których można wyróżnić uchwalanie lub zmianę statutu, określenie programów partii, podejmowanie uchwał w sprawie rozwiązania partii lub jej połączenia z innymi ugrupowaniami, przyjmowanie sprawozdań organów, czy też wybór najważniejszych organów danego stronnictwa (o ile nie wybierane są one w wyborach powszechnych).

Wracając do stałych organów uchwałodawczych, warto podkreślić, że także i w tym przypadku zróżnicowane jest ich nazewnictwo ${ }^{29}$. W odróżnieniu od Kongresu (Konwencji) organy uchwałodawcze w postaci rad mają charakter stały, sprawując swoje funkcje w okresie pomiędzy Kongresami (Konwencjami). W dużej mierze zbieżne są też kompetencje tego typu organów, przede wszystkim z wyznaczaniem kierunków i programów działania partii, choć niekiedy wyłącznie w obrębie wyznaczonym przez uchwały Kongresu (Konwencji), a także rozstrzyganie o niektórych sprawach personalnych, w tym wyłanianiu lub zatwierdzaniu kandydatów w wyborach. Pewne podobieństwa można również odnaleźć w składzie rad. W zasadzie każdy z badanych statutów przewiduje, że w skład rad pewne osoby wchodzą z urzędu. Dotyczy to osób piastujących najwyższe stanowiska w partii (np. szef partii, jego zastępcy, członkowie organu

a w sytuacji, gdy partia przekroczy 10 tysięcy członków, jeden delegat przypadać będzie na dwudziestu członków w okręgu.

${ }^{25}$ Zgodnie z art. 13 ust. 1 pkt 5 liczba delegatów wybieranych przez Zjazdy Okręgowa musi być co najmniej dwukrotnie większa od liczby delegatów obejmujących mandat z racji funkcji pełnionych w partii lub organach publicznych.

${ }^{26}$ Zob. art. 21 ust. 2 lit. d Statutu SLD, § 4 ust. 2 Statutu PO, art. 14 Statutu PSL, art. 24 ust. 2 Statutu Partii Razem, przy czym ta partia wybory delegatów traktuje jako wyjątek od zasady, zgodnie z którą w obradach Kongresu może brać udział każdy z członków partii.

27 Np. w PiS mandaty takie uzyskują: Prezes Honorowy, Prezes, członkowie Rady Politycznej, Krajowej Komisji Rewizyjnej, Sądu Dyscyplinarnego, Przewodniczący Rad Regionalnych, w PO - członkowie Rady Krajowej, Krajowej Komisji Rewizyjnej i Krajowego Sądu Koleżeńskiego, w PSL - Prezes i Przewodniczący Rady Naczelnej, prezesi zarządów wojewódzkich, honorowy prezes, członkowie Rady Naczelnej, członkowie Głównej Komisji Rewizyjnej, Głównego Sądu Koleżeńskiego i Krajowy Rzecznik Dyscyplinarny.

${ }^{28}$ Rozwiązania takie przewidują statuty: PiS, PSL, PO i Nowoczesnej (w tych dwóch ostatnich przypadkach dotyczy to tylko posłów, senatorów oraz członków PE).

29 Może Być to Rada Polityczna (PiS), Rada Naczelna (PSL), Rada Krajowa (PO, Nowoczesna, SLD, KORWiN, Razem). 
wykonawczego, przewodniczący jednostek terenowych wyższego szczebla), parlamentarzystów (poza partią KORWiN i PSL). Resztę członków stanowią osoby, które uzyskują mandat z wyborów, przy czym wybory te $\mathrm{z}$ reguły wybierane są w całości przez Kongres (Konwencję) ${ }^{30}$. Liczba takich członków jest niejednorodna. $\mathrm{Z}$ reguły w partiach o większej bazie członkowskiej przekracza ona sto osób (PiS do 120 osób, PO - 120 osób, SLD - do 150, w PSL łącznie z osobami pełniącymi funkcje partyjne liczebność Rady Naczelnej nie może przekraczać 130 członków). W mniejszych ugrupowaniach jest to już liczba znacząco mniejsza (KORWiN - do 25 członków z wyboru, Nowoczesna - 16 członków, Razem nie mniej niż 20 członków).

Analiza statutów partyjnych nakazuje podkreślić, że w SLD występuje jeszcze dodatkowy organ uchwałodawczy, jakim jest Konwencja Krajowa, którą można uznać za formę pośrednią pomiędzy Kongresem a Radą Krajową. W jej skład wchodzą członkowie tego ostatniego organu, członkowie Krajowego Sądu Partyjnego oraz Krajowej Komisji Rewizyjnej, a także osoby wybrane przez organy wojewódzkie. W niektórych sprawach Konwencja może zastępować Kongres (zmiana statutu, uzupełnienie wyboru wiceprzewodniczących), ale również może zwoływać Kongres czy decydować o przeprowadzeniu powszechnych wyborów przewodniczącego partii (art. 23 i 24 statutu SLD).

Wszystkie badane ugrupowania posiadają również organy kontrolne (Krajowa Komisja Rewizyjna, Komisja Rewizyjna, Główna Komisja Rewizyjna) oraz sądy partyjne (Krajowy Sąd Partyjny, Sąd Partyjny, Krajowy Sąd Koleżeński, Sąd Koleżeński, Główny Sąd Koleżeński, Koleżeński Sąd Dyscyplinarny), które dysponują możliwością sankcjonowania niewłaściwego zachowania członków partii i ich organów, z wykluczeniem takiej osoby z partii włącznie. Natomiast jedynie statut Partii Razem przewiduje występowanie - jako stałego organu partyjnego - Partyjnej Komisji Wyborczej, której zadaniem jest przygotowywanie projektów zasad przeprowadzenia wyborów organów partii, nadzorowanie przebiegu takich wyborów i stwierdzanie ich ważności).

Podobnie jak w przypadku ukształtowania organów centralnych, partie polityczne w Polsce mają swobodę kształtowania struktury terenowej, co również skutkuje daleko idącymi odmiennościami w uregulowaniu takich struktur terenowych. Dotyczy to zarówno organów na niższych poziomach, jak również liczby szczebli takich struktur. Najbardziej rozbudowane struktury terenowe posiadają PSL i SLD, w których przyjmują one kształt czteroszczeblowy. W obu tych

${ }^{30}$ Od tej zasady są wyjątki, gdyż w SLD osoby takie wyłaniają organizacje wojewódzkie, w PSL część członków Rady Naczelnej wybiera Kongres, a część zjazdy wojewódzkie, zaś w Partii Razem wybory mają powszechny charakter. 
partiach podstawową jednostką organizacyjną partii jest koło, które winno liczyć co najmniej 5 członków. Funkcjonują one na poziomie gminy lub jej jednostek pomocniczych. Koła grupują się w gminne organizacje partyjne, posiadające swoje organy zarządzające i uchwałodawcze. Kolejnym szczeblem są powiatowe organizacje partyjne, a te wchodzą w skład wojewódzkich organizacji partyjnych, które również posiadają swoje organy na tych szczeblach. W obu partiach struktura terenowa w dużej mierze oparta jest o organizację terytorialną państwa.

Nowoczesna także posiada czteroszczeblową organizację struktur partyjnych, z tym, że jest ona inaczej podzielona. Podstawową jednostką również jest koło (działające na poziomie gminy, a w miastach powyżej stu tysięcy tworzone mogą być koła dzielnicowe), lecz te kreują powiatową organizację partyjną. Te ostatnie wchodzą w skład okręgu, zarządzanego przez koordynatora. Okręgi odpowiadają podziałowi na okręgi wyborcze, co w założeniu ma ułatwiać realizację funkcji wyborczej tej partii. Nadrzędną jednostką organizacyjną jest region, który obejmuje województwo ${ }^{31}$, o zdecydowanie bardziej rozwiniętej strukturze organów partyjnych.

Trzyszczeblową strukturę terytorialną przewidują statuty PO i PiS, choć w obu przypadkach wyglądają one odmienne. W PO - podobnie jak w większości partii - podstawową jednostką organizacyjną jest koło, które może przybierać postać terytorialną lub środowiskową, przy czym te ostatnie nie mogą na terenie powiatu stanowić większości kół. Rozstrzygnięcie o powołaniu koła należy do zarządu regionalnego. Drugim szczeblem organizacyjnym są powiaty, z tym, że jeśli na jego terenie jest tylko jedno koło, struktura ta nie musi być powołana. Najwyższą strukturę terytorialną stanowią regiony, obejmujące jedno lub więcej województw ${ }^{32}$. Zarówno na szczeblu powiatu, jak też regionu funkcjonują zarówno organy uchwałodawcze, jak i wykonawcze. Natomiast w PiS podstawową jednostką organizacyjną jest komitet, który może mieć charakter terytorialny oraz środowiskowy, z tym, że w tym ostatnim przypadku winien on grupować członków z jednego województwa, a nie powiatu, jak w przypadku PO. Drugim szczeblem ${ }^{33}$ jest okręg, który pokrywa się z granicami okręgów wyborczych w wyborach do Sejmu. Co specyficzne, na tym poziomie, podobnie jak i na poziomie komitetu, istnieją wyłącznie stałe organy wykonawcze, zaś organami wykonawczymi są zgromadzenia (zjazdy lub zebrania wszystkich

31 Przy jednoczesnym wydzieleniu miasta stołecznego Warszawy.

${ }^{32} \mathrm{~W}$ praktyce ustrojowej PO funkcjonuje jednak 17 regionów, przy czym 15 nich pokrywa się z granicami województw, zaś dwa pozostałe są wynikiem wyodrębnienia dwóch regionów w województwie mazowieckim.

${ }^{33} \mathrm{~W}$ przypadku, gdy na terenie powiatu funkcjonują co najmniej 3 komitety powoływane są również władze powiatowe w postaci Zarządu Powiatowego. 
członków). Dopiero na szczeblu regionów, pokrywających się z województwami, występują stałe organy uchwałodawcze i wykonawcze, choć charakter tego pierwszego (Rady Regionalnej) jest dyskusyjny, z racji wykonywania przez nią również pewnych kompetencji wykonawczych.

Wyłącznie dwie stosunkowo młode partie pozaparlamentarne - Razem i KORWiN przyjęły struktury dwuszczeblowe, choć w tym pierwszym przypadku sytuacja nie jest tak oczywista, zasadniczo bowiem jej podstawową jednostką organizacyjną jest okręg, który obejmuje swoim obszarem działania przynajmniej terytorium jednego powiatu. Na poziomie okręgu funkcjonuje Walne Zebranie Członków jako organ uchwałodawczy oraz Zarząd, przy czym w sytuacji, gdy okręg liczy co najmniej 60 członków może być również powołany przedstawicielski organ uchwałodawczy w postaci Rady Okręgu. Natomiast organem stopnia wyższego stanowi województwo z funkcjonującą tam Radą Wojewódzką, choć jeśli w województwie funkcjonuje wyłącznie jeden okręg, to kompetencje tego organu przejmuje Rada Okręgu. Poza tymi dwoma szczeblami mogą być również powoływane koła stanowiące jednostkę pomocniczą okręgu, które mają za zadanie ewentualne usprawnienie pracy okręgu.

Partia KORWiN posiada natomiast dwie jednostki terytorialne. Podstawową jest okręg pokrywający się z okręgiem wyborczym w wyborach do Sejmu, a kolejny, wyższy szczebel stanowią regiony pokrywające się z granicami województw. O ile władze na poziomie okręgu są rozbudowane i posiadają zarówno organy uchwałodawcze (Zebranie Członków i Rada Okręgu), oraz wykonawcze (Zarząd i Prezes Zarządu), to na poziomie regionów funkcjonuje już wyłączenie Zarząd Regionu i Prezes Zarządu Regionu. W skład tego pierwszego wchodzą członkowie Zarządów Okręgu, natomiast Prezesa arbitralnie powołuje Prezes Partii po zasięgnięciu opinii Prezydium Zarządu Krajowego. Podobnie jak w Partii Razem mogą powstawać również koła na poziomie dzielnic, gmin i powiatów, a na poziomie tego ostatniego również oddziały, przy czym obie te struktury są jedynie jednostkami pomocniczymi. Ich powstanie warunkowane jest uzyskaniem zgody odpowiednio Zarządu Regionu (a w przypadku odmowy lub niepodjęcia uchwały w ciągu 14 dni - Prezydium Zarządu Krajowego) albo Zarządu Okręgu.

Zasady funkcjonowania organizacji terenowych są niezwykle zróżnicowane i poziom demokratyczności rozstrzygnięć przez nie podejmowanych też nie może zostać jednolicie oceniony. Owa demokratyczność najlepiej prezentuje się na najniższym poziomie organizacyjnym, gdzie standardem jest bezpośrednie rozstrzyganie spraw leżących $w$ gestii takiej struktury organizacyjnej na zebraniach zgromadzeniach wszystkich członków tej jednostki. Natomiast już zdecydowanie gorzej sytuacja wygląda na poziomie struktur wyższego rzędu, gdzie 
powszechne zebrania członków należą do rzadkości ${ }^{34}$. W ich przypadku dominują organy o charakterze przedstawicielskim, często z resztą z udziałem osób pełniących funkcje partyjne na niższych szczeblach. Osobną kwestią jest zakres samodzielności takich struktur i ich uprawnienie, chociażby w sferze pozostawienia im swobody zawierania koalicji politycznych na poziomie lokalnym. Niezależność organizacji terenowych w tym zakresie w zasadzie posiadają organy terenowe Partii Razem (Walne Zgromadzenie Okręgu), PO (rada w powiecie), SLD (rady powiatowe i wojewódzkie) oraz Nowoczesnej (Rady Regionu) ${ }^{35}$.

Mówiąc o demokracji wewnątrzpartyjnej nie sposób nie wspomnieć też o rozwiązaniu, które przewiduje statut Razem (art. 59-60), a mianowicie o referendum wewnątrzpartyjnym, które może dotyczyć maksymalnie trzech kwestii rozstrzyganych za pomocą odpowiedzi „tak” lub „nie”. Zarządza je Zarząd Krajowy z własnej inicjatywy lub na wniosek Rady Krajowej, co najmniej 1/10 członków partii ${ }^{36}$ lub zarządów co najmniej 1/4 okręgów. Referendum takie będzie uznane za ważne, jeśli uczestniczyło w nim co najmniej $25 \%$ członków. Nie musi ono być jednak wiążące, gdyż jeśli ma mieć taki charakter, powinno to zostać wskazane we wniosku o jego przeprowadzenie. Jeśli będzie ono miało taki charakter, to moc rozstrzygnięcia podjętego w ten sposób ma wagę uchwały kongresu. Co istotne, statut nie określa sposobu przeprowadzenia referendum, pozostawiając Radzie Krajowej kompetencję do przyjęcia szczegółowych regulacji.

Podsumowując, trzeba stwierdzić, że w polskim porządku ustrojowym wewnętrzna organizacja partii politycznych należy do sfery statutowej, co daje takim podmiotom daleko idącą swobodę ich ukształtowania, pod warunkiem, że ukształtowanie to będzie oparte na zasadach demokratycznych. Nie jest jednak określone, w jakim stopniu demokratyczność struktur partyjnych ma być zachowana. Przyjąć więc trzeba, że w praktyce wyłączone jest jedynie istnienie takich ugrupowań, w których brak byłoby rozwiązań pozwalających na wyłanianie najważniejszych organów na drodze wyborów, np. poprzez ich imienne wskazanie czy też brak kadencyjności takich organów. Mimo to problemem, o którym warto wspomnieć jest brak możliwości badania przez TK zgodności statutu partii politycznej z Konstytucją oraz ustawą o partiach politycznych, TK bada jedynie zgodność jej celów lub działalności ustawą zasadniczą. Jak trafnie zauważył

34 Tego typu podmioty występują wyłącznie w PiS na poziomie okręgu (nie ma ich w regionie), w PSL na poziomie gminy, o ile organizacja taka liczy nie więcej niż 100 członków, opcjonalnie w SLD na poziomie gminy oraz powiatu.

${ }^{35} \mathrm{~W}$ pozostałych badanych statutach podobne kompetencje można interpretować z treści przepisów, choć np. w przypadku PiS nadzór nad takimi porozumieniami sprawowany jest Radę Polityczną, co znacząco osłabia samodzielność struktur terytorialnych (art. 17, pkt 4 statutu).

${ }^{36}$ Członkowie z jednego okręgu nie mogą stanowić jednak więcej niż 1/3 wnioskujących. 
M. Granat: „takie wąskie ujęcie kognicji Trybunału nie w pełni jest zharmonizowane z przedstawionymi przepisami ustawy o partiach politycznych, w której mowa jest również o kontroli zasad działania partii, a także o wszczynaniu postępowania $\mathrm{w}$ razie wprowadzenia do statutu zasad niezgodnych $\mathrm{z}$ art. 8 tej ustawy" 37 .

\section{BIBLIOGRAFIA:}

Chmaj M., Sokół W., Żmigrodzki M., Teoria partii politycznych, Lublin 1997.

Complak K., Normy pierwszego rozdziału Konstytucji RP, Wrocław 2007.

Granat M., Partie polityczne w konstytucjach państw Europy Środkowej $i$ Wschodniej, w: Partie polityczne we wspótczesnym konstytucjonalizmie, red. M. Granat, P. Policastro, J. Sobczak, Lublin 2001.

Granat M., Gorgol A., Sobczak J., Ustawa o partiach politycznych. Komentarz, Warszawa 2000.

Sobczak J., Konstytucyjna wolność tworzenia partii politycznych w Polsce, w: Partie polityczne we wspótczesnym konstytucjonalizmie, red. M. Granat, P. Policastro, J. Sobczak, Lublin 2001.

Sobolewski M., Zasady demokracji burżuazyjnej i ich zastosowanie, Warszawa 1969.

Sokolewicz W., Uwaga 18 do art. 13, w: Konstytucja Rzeczypospolitej Polskiej. Komentarz, $t . V$, red. L. Garlicki, Warszawa 2007.

Wachlowski Z., Stronnictwa polityczne w państwie wspótczesnym, Warszawa 1939

Wiśniewska A., Dramat partii Razem, Dziennik Opinii 2015, nr 295 (1079).

${ }^{37}$ Zdanie odrębne sędziego TK Mirosława Granata do uzasadnienia postanowienia Trybunału Konstytucyjnego z dnia 6 kwietnia 2011 r., Pp 1/10, OTK ZU z 2011 r., nr 3A, poz. 27. 